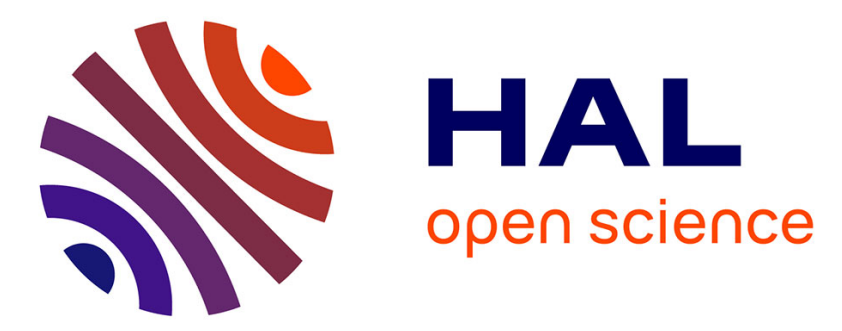

\title{
POPULATION KINETICS IN ERBIUM DOPED LASER CRYSTALS PRODUCED BY EXCITATION WITH AN Er: GLASS LASER AT 1.53 MICRONS
}

M. Birnbaum, K. Spariosu, B. Viana

\section{- To cite this version:}

M. Birnbaum, K. Spariosu, B. Viana. POPUlATION KINETICS IN ERBIUM DOPED LASER CRYSTALS PRODUCED BY EXCITATION WITH AN Er: GLASS LASER AT 1.53 MICRONS. Journal de Physique IV Proceedings, 1991, 01 (C7), pp.C7-422-C7-422. 10.1051/jp4:19917110 . jpa00250759

HAL Id: jpa-00250759

https://hal.science/jpa-00250759

Submitted on 1 Jan 1991

HAL is a multi-disciplinary open access archive for the deposit and dissemination of scientific research documents, whether they are published or not. The documents may come from teaching and research institutions in France or abroad, or from public or private research centers.
L'archive ouverte pluridisciplinaire HAL, est destinée au dépôt et à la diffusion de documents scientifiques de niveau recherche, publiés ou non, émanant des établissements d'enseignement et de recherche français ou étrangers, des laboratoires publics ou privés. 


\section{POPULATION KINETICS IN ERBIUM DOPED LASER CRYSTALS PRODUCED BY EXCITATION WITH AN Er: GLASS LASER AT 1.53 MICRONS}

M. BIRNBAUM, K. SPARIOSU and B. VIANA ${ }^{(1)}$

Center for Laser Studies, University of Southern Califomia, Deparment of Electrical Engineering, University Park, DRB 17, Los Angeles, California 90089-1112, USA

It is well-known that upconversion limits the performance of Er:crystal lasers at $1.6 \mu\left({ }^{4} I_{13 / 2-}\right.$ $\left.>4 I_{15 / 2}\right)$. The ion-ion interaction consists of $\operatorname{Er}(13 / 2)+\operatorname{Er}(13 / 2) \rightarrow \operatorname{Er}(9 / 2)+\operatorname{Er}(15 / 2)$. Thus each upconversion event leads to a loss of inversion by three. The following crystals were irradiated with the focussed light c'stput of an Er:glass laser at $1.53 \mu$ which provided a spiked output for about $1 \mathrm{~ms}$ anc total energy about $200 \mathrm{~mJ}$ : $\operatorname{Er}(0.1,0.2,0.5,1,2,4 \%): Y A G, \operatorname{Er}(5 \%): Y A L O, \operatorname{Er}(10 \%): Y L F, \operatorname{Er}(25 \%): Y S G G$, and Er(10\%):YSO. In all cases, absorption of the $1.53 \mu$ radiation produced "bleaching", namely, reduced absorption resulting from depletion of the ground level of $E_{r}$, which becomes saturated (maximum transmission of $1.53 \mu$ light).

The division of population between the ground levels of the ${ }^{4} I_{15 / 2}$ manifold and the ${ }^{4} I_{13 / 2}$ manifold was calculated from the changes in absorption coefficient induced by depletion of the ground ;tate. Using the Boltzmann distribution, we computed the populations in the sublevels of the $15 / 2$ and the 13/2 manifolds and found that a very large inversion was produced between the lowest sublevel of :he 13/2 manifold and the highest lying sublevel of the 15/2 manifold. The length or thickness of our rrystal samples $(0.1$ to $1 \mathrm{~cm})$ together with the computed inversion showed that there was ample gain to iustain laser action. Experiments are in progress to demonstrate laser action with the 1.53 $\mu$ Er:glass lase sump.

Green light $(560 \mathrm{~nm})$ and infrared $(980 \mathrm{~nm})$ fluorscence was observed for all the crystals under $1.53 \mu$ excitation. These measurements will be used to obtain the upconversion coefficients and to fetermine the deleterious effects of upconversion on Er:crystal lasers. The focus of these studies is the letermination of the potential utility of Er:crystals for development of an efficient room temperature ir:crystal laser at $1.6 \mu$.

Lab. de Chimie Appl. de l'Etat Solide, Universite Pierre et Marie Curie, Ecole Nationale Superieure de Zhimie de Paris, 11, rue Pierre et Marie Curie 75231 Paris Cedex 05, France. 